Article

\title{
Effects of Commercial Activities by Type on Social Bonding and Place Attachment in Neighborhoods
}

\author{
Byungsuk Kim ${ }^{1}$ and Jina Park ${ }^{2, *}$ \\ 1 Department of Urban Planning, Hanyang University, Seoul 04763, Korea; bsk0728@nate.com \\ 2 Department of Urban Planning and Engineering, Hanyang University, Seoul 04763, Korea \\ * Correspondence: paran42@hanyang.ac.kr; Tel.: +82-2-2220-0332
}

Received: 20 March 2018; Accepted: 24 May 2018; Published: 29 May 2018

\begin{abstract}
Place attachment is an emotion that people experience in connection to a specific place and it is needed to maintain a sustainable neighborhood community. The emotion is affected by various factors, such as experience, function, environment, and satisfaction. This study focuses on commercial structures, which are one feature that characterizes the physical environments of neighborhoods. The aim of this study is to determine the effects of commercial activities in different commercial environments on social bonding and place attachment in residents. Two sites were selected for analysis due to their different commercial environments, and path analysis was used to examine the relationships among factors. The results indicate that commercial activities, which can vary according to commercial type, had both direct effects and indirect effects through social bonding between residents on place attachment. These results suggest that the commercial environment is an important element affecting the community and place attachment of residents in neighborhoods.
\end{abstract}

Keywords: place attachment; commercial types; commercial activities; social bonding; physical activities

\section{Introduction}

In light of the emotions, intimacy, and happiness that people feel in connection to their neighborhoods, there is more than functional and physical meaning to neighborhoods. The emotional ties of residents to the area in which they live can be defined as place attachment to a neighborhood. Analysis of such has been extensively addressed in looking at the emotional experiences of people and people's ties to places in terms of various factors of function and satisfaction [1-4]. Place attachment is a concept similar to residential satisfaction in terms of cognition about a physical environment, with one important distinction. If residential satisfaction is a functional evaluation of a place of residence from the viewpoint of the people living there, then place attachment is an emotional evaluation of the place of residence. In order to foster a salubrious neighborhood, it is necessary to consider not only the functional aspects of a place, but also the psychological and emotional demands of human beings. In this context, place attachment can be an important criterion of residential environment evaluation [5]. Since place attachment is formed when a person is psychologically connected to a specific place, it can be a source of relief for residents amid the rapid changes of modern urban environments.

Place attachment can be formed by various factors. In the work of Lewicka [6], which analyzed the studies of place attachment within the past 40 years, various variables including socio-demographic, social, and physical predictors are identified in place attachment. Many of the previous studies related to place attachment in neighborhoods have been conducted in terms of the influence of physical environment characteristics on place attachment in local residents [7-11]. This is because place attachment is basically an emotional bond that a person has with a place. On the other hand, some studies $[4,7,9]$ have analyzed the influence of social bonds on place attachment, focusing on the 
social ties of residents of a neighborhood. Additional other studies $[7,12,13]$ have investigated the influence of people's personal characteristics on place attachment.

Overall, research results show that physical environment characteristics such as place, personal characteristics of individual residents, and characteristics of social relationships between residents influence the formation of place attachment among locals. Based on these results, the focus of this study is the relationships among these various physical environment characteristics and place attachment. Beyond the influence of place attachment on individual variables, it is necessary to clarify the mechanism of the relationship of structural influence among the features of physical environments, the personal characteristics of residents, and social bonding. In order to establish the relationship between place attachment and its influencing variables, it is necessary to understand the interaction between people and place — as well as between people and people-in the physical features of neighborhoods. In this study, we focus on "activities" as a key parameter in our understanding of the relationships between the variables affecting place attachment.

From the perspective of environmental psychology, human activities arise in the context of an environment. Many studies have demonstrated the relationships between physical environment and people's activities [14-17]. If the neighborhood environment affects people's activities, and if the activities affect the level of place attachment, then it is possible to discuss which characteristics of a neighborhood environment ultimately promote place attachment. If the unique physical environment of a neighborhood increases the amount and types of activities pursued by its residents-thereby positively impacting place attachment-then physical environment characteristics stand to provide urban design implications for a salubrious neighborhood.

Among various activities that occur in a neighborhood, this study focuses on commercial activities. Commercial activities are basic, essential activities in people's daily lives. Depending on the type of commercial facility, however, the style of activities can be very different. Various types and characteristics of commercial facilities are identified based on their location, usage, and surroundings, but commercial facilities can be compared in two basic forms: street shops, which are located along the streets of residential environments, and mall-type shops, describing a configuration in which shops are concentrated in specific buildings (in contrast to street shops). In terms of the commercial environment of a neighborhood, this difference in commercial form can impact the commercial activities of residents. As a result, the distinction can manifest as a difference in neighborhood activities. In a neighborhood with small shops, small quantities of goods are frequently purchased. In contrast, in a neighborhood with large marts, large amounts of goods are purchased less frequently. Additionally, if an individual uses a car to purchase a large quantity of goods, then the individual may have fewer opportunities to come into contact with her or his neighbors and have less interaction with the neighborhood environment than when walking on foot. Thus, these differences in commercial activities may lead to differences in face-to-face opportunities among human beings. The activities of the residents in a neighborhood can be a driving force for local initiatives such as local revitalization and community spirit.

In this respect, commercial forms affect the physical activities of people and are, therefore, an important subject of study in terms of social bonding among residents in a neighborhood and the promotion of place attachment. Various physical elements of neighborhoods have been studied, including walkability $[17,18]$, street connectivity [19], land-use mix [15,16], pedestrian and traffic safety [20], and recreation facilities and parks [16]. In contrast, however, few studies have focused on the physical elements of commercial activities and commercial types-one of the basic activities of people's daily lives. Indeed, there are no studies to analyze relationships among the influencing factors of place attachment, such as the effects of commercial form on people's commercial activities and the effects of commercial activities on social bonding and place attachment. Therefore, this study investigates the effects of "activities" as a function of commercial form in relation to the physical environment of a neighborhood, social bonding between residents, and place attachment. 


\section{Previous Studies}

\subsection{Place Attachment}

The concept of attachment can be applied to explain the relationship between human beings and the environment (that is, our interest in a specific place or community), although the concept is mainly described in terms of people's connection to other people, such as infants and parents or family and friends. Recent research has focused on attachments and so-called place attachments in terms of "friendliness to physical places" in contrast to the relationship networks between people that are emphasized in sociological research. Place attachment can be understood in two dimensions: place identity and place dependence [21]. Proshansky [22] defines place identity as "a complex pattern of beliefs, values, feelings, expectations, and preferences relevant to the nature of the physical world," which is a complex cognitive structure of a person at a specific place. Place dependence is a functional relationship with a person's residence (or other specific area) and may be explained by comparing one place with another according to individual needs. In this sense, place dependence is defined in terms of whether a particular area or facility functions in accordance with a user's activities [23].

Place attachment is a complex concept that describes the interaction of emotional or symbolic relationships, emotions that are formed in a single physical environment, and human interrelationships and feelings occurring in that particular place. In other words, place attachment shows the ways in which a place is more than just a physical environment. Place attachment arises not only from the place itself, but also from emotions due to consciousness, experience, psychological reaction, symbolism, and other complex functions of cognition that people associate with the place [24]. Thus, we can define place attachment as being caused by empirical experiences that occur when people consistently interact with a specific place. From this point of view, if the residents in a neighborhood engage in continuous visits and activities in a specific place, a positive relationship may be found between people and place in the form of place attachment.

\subsection{Place Attachment in Neighborhoods}

Place attachment refers to an emotional factor between people and physical spaces. In this context, research trends related to place attachment have examined personal, social, and regional differences in place attachment, together with the factors affecting place attachment. Existing research mainly deals with personal and social variables (such as race, age, and economic power), time variables (such as duration of residence and satisfaction with the local environment), and spatial characteristics. This multifactorial lens suggests the complexity of the feeling of place attachment.

It is generally accepted that levels of satisfaction with people's residential environments are highly related to place attachment [7-11]. In order to maintain place attachment, certain neighborhood environment standards must be achieved. In declining residential areas, the level of attachment of people to their place of residence will decline, and relocation will be considered due to deterioration of the quality of life [25]. Place attachment occurs mainly through neighborhood environments and in bonding with neighbors. Neighborhood satisfaction, which is a passive, direct experience-as opposed to social bonding with neighbors (which needs to be actively pursued during settlement in a new local environment or following neighborhood redevelopment)_plays an important role in the formation of place attachment [4]. In addition, place attachment has different characteristics depending on the scale of a place, such as a city versus a smaller neighborhood [2,26].

In the physical environment of a neighborhood, place attachment changes according to the personal and social characteristics of the people directly experiencing place attachment. There are differences depending on whether people reside in a home of their own, on race [7], and on whether people are indigenous or immigrants [12]. If there is a link between residents and a neighborhood wherein place attachment is formed, positive effects are noted in the neighborhood environment. Home ownership, race parity, and indigenous people inspire a sense of belonging to an area. In this respect, bonding with neighbors is an important factor in place attachment. When this bond 
is strong, place attachment is positively affected $[4,7,9]$. On the contrary, if there is a low level of solidarity among residents and people move frequently, the formation of place attachment can be difficult [3]. To increase social bonding between neighbors, contact with neighbors and time spent together must increase. In other words, the accumulation of experience in the neighborhood is important, and experience is generally proportional to time. A variable that represents this relationship in the context of neighborhoods is duration of residence. Many studies have shown that residence period has an impact on place attachment $[7,9,27,28]$.

In order to foster strong social bonding and place attachment among residents, residents should be active in their neighborhood, and the neighborhood environment should reflect their desires. The physical environment of various neighborhoods is related to the activities of people. Especially, focusing on commercial environments, it has been found that mixed-land use [15], retail floor area ratio [29], and commercial facilities [30,31] affect people's walking activities. Walking also positively affects resident bonding [32], and walking-friendly neighborhood conditions can improve people's sense of community $[33,34]$. This correlation explains the importance of a neighborhood's physical environment relative to the amount and types of activities that occur therein in the context of place attachment. Accordingly, this study aims to investigate the effects of commercial activities on social bonding by neighborhood commercial types, together with the impact on place attachment.

\section{Methods}

\subsection{Study Areas}

Neighborhoods characterized by different types of commercial structures were selected in order to analyze the relationship among commercial types, commercial activities, social bonding, and place attachment. The distinction is between commercial types of street shops or a shopping mall. First, Lancry in Paris, France, was selected to represent the street shops type (see. Figure 1). The whole area is characterized by medium-rise buildings with an average of six to seven floors. On the first floors of buildings, various small shops including commercial, service, and manufacturing shops are located along the street. The upper parts of the buildings are composed of residential living spaces. Lancry is included in a grouping of 11 regions that comprise the business district of Vital'Quartier, initiated in 2004 by the Société d'Economie Mixé d'Aménagement de l'Est de Paris (SEMAEST) as part of the commercial revitalization project in Paris. It can be seen as a commercial type of street shop.
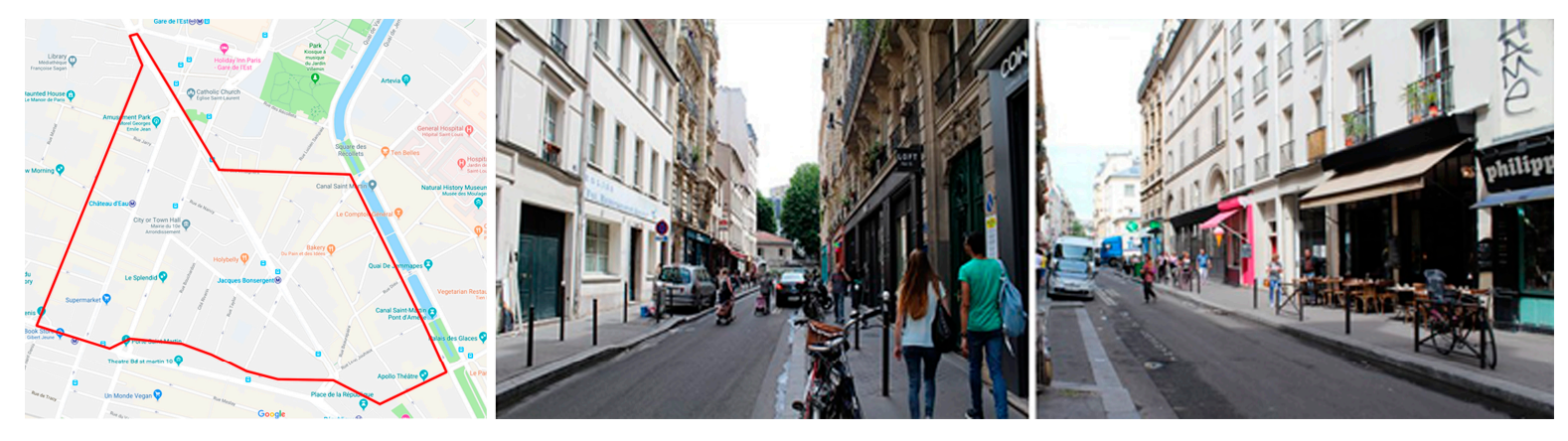

Figure 1. Lancry.

The opening of large shopping malls in Paris is regulated by law as "La loi Royer" (1973) and "La loi Raffarin" (1996) and permission is required to open stores over $300 \mathrm{~m}^{2}$ by Raffarin law. For this reason, mall-type commercial areas should be chosen outside of Paris. La Défense was chosen as a representative shopping mall type among commercial areas (as compared to street shop type). La Défense (see Figure 2) is a representative new town in France and has two large shopping malls (CNIT and Quaten Temps). Thus, unlike the street shops seen in Paris, large, mall-type commercial facilities are used by residents of La Défense for various shopping activities. 

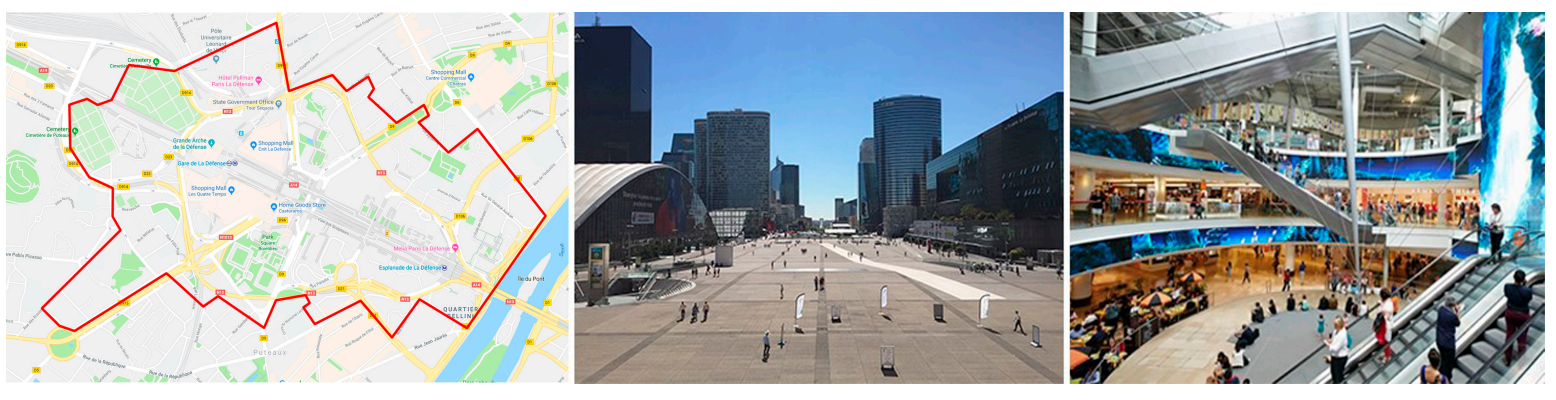

Figure 2. La Défense.

The average age of residents in Lancry is 37 years old and the population density is $38,160 / \mathrm{km}^{2}$. There are 6.1 stores per $100 \mathrm{~m}$ among bars, cafes, and restaurants, and 26.8 stores per $100 \mathrm{~m}$ among all kinds of shops. The housing density in Lancry is $244 \mathrm{log}$./ha [35]. La Défense is distributed across three zones-Courbevoie, Puteaux, and Nanterre. In this study, the average values for Fb de l'Arche (Courbevoie), Gambetta (Courbevoie), and La Défense (Puteaux) were used. In the case of La Défense, the average age is 35.33 years with a population density of $17,836.67 / \mathrm{km}^{2}$. There are, on average, 1.57 shops for bars, cafes and restaurants, with an average of 9.53 stores per $100 \mathrm{~m}$. The housing density in La Défense is $94.67 \mathrm{log}$./ha [36]. This information indicates that Lancry has a higher density of shops than La Défense, which means that the residents in Lancry have a higher accessibility to shops than La Défense.

\subsection{Variable Settings}

First, the two commercial types were changed to dummy variables (street: 1, mall: 0) to determine the effects of the commercial types. The weekly shopping frequency of residents depending on the commercial type was measured to represent levels of commercial activities (1 to 5 points). Aspects of social bonding were established as variables to determine whether bonding among residents affects place attachment, and the items were related to levels of closeness among neighbors. Place attachment variables were measured using place identity (measured by a fundamental question about the extent to which residents feel attached to their neighborhood) and place dependence, which is a functional necessity.

By definition, place attachment is affected by levels of attachment in residents to a specific place. Accordingly, neighborhood environments and place attachment have been the main subjects of previous research. In this study, the following variables were set as environmental factors in order to scrutinize environmental factors through an analytical lens. First, parameters of "satisfaction with commercial infrastructure" and "satisfaction with commercial quality" were set in terms of commercial environment satisfaction. Two variables were set to determine whether the physical features of commercial environments influence place attachment or whether qualitative factors of shops have effects on place attachment. In addition, the variable of "satisfaction with neighborhood facilities" was set in order to confirm the effects of neighborhood environments in the findings of previous research on place attachment.

\subsection{Questionnaires and Data Collection}

Table 1 shows that questionnaires consisted of items about place attachment, social bonding, commercial satisfaction, and resident satisfaction with neighborhood facilities. The items related to place attachment and social bonding were reconstructed based on previous studies $[9,11,37]$. The items on commercial satisfaction and neighborhood satisfaction were constructed based on the activities and direct experiences of the residents in the neighborhoods. Complete questionnaires included five items on place identity, five items on place dependency, five items on social bonding, eight items 
on commercial satisfaction, and six items on neighborhood satisfaction. All of the above items were measured on a five-point scale.

Table 1. Questionnaire items.

\begin{tabular}{|c|c|c|}
\hline \multicolumn{2}{|c|}{ Factors } & Items \\
\hline \multirow{2}{*}{ Place attachment } & Place identity & $\begin{array}{l}\text { This neighborhood is important in my life. } \\
\text { I say that I live in this neighborhood when I introduce myself. } \\
\text { If someone asks me about this neighborhood, I can answer the questions. } \\
\text { I am proud to live in this neighborhood. } \\
\text { This neighborhood is special to me. }\end{array}$ \\
\hline & Place dependence & $\begin{array}{l}\text { This neighborhood is suitable to my line of work. } \\
\text { This neighborhood is better to live in than other neighborhoods } \\
\text { I do many activities around this neighborhood. } \\
\text { Leaving this neighborhood causes me to feel sad. I would live in this } \\
\text { neighborhood even if I had the chance to move to other areas. }\end{array}$ \\
\hline \multicolumn{2}{|c|}{ Social bonding } & $\begin{array}{l}\text { I know the residents of my neighborhood well. } \\
\text { I have friendly neighbors to talk to. } \\
\text { I have many friends in the neighborhood. } \\
\text { I attend neighborhood gatherings often. } \\
\text { I attend the event of neighborhood often. }\end{array}$ \\
\hline \multicolumn{2}{|c|}{ Satisfaction with commerce } & $\begin{array}{l}\text { Number of shops, types of shops, necessary shops, price of products, } \\
\text { service of shops, type and quality of products, distance to shops. }\end{array}$ \\
\hline \multicolumn{2}{|c|}{ Commercial activities } & Shopping frequency. \\
\hline \multicolumn{2}{|c|}{ Satisfaction with neighborhood facilities } & $\begin{array}{l}\text { Green space, public and cultural facilities, public transportation, } \\
\text { education services, safety, pedestrian environment. }\end{array}$ \\
\hline \multicolumn{2}{|c|}{ Commercial type } & $\begin{array}{l}\text { Street shops-type neighborhood: Lancry. } \\
\text { Mall type-neighborhood: La Défense. }\end{array}$ \\
\hline
\end{tabular}

Note. Place identity and place dependence items, as well as social bonding items, are in a designated order (e.g., identity 1, identity 2); Commercial type: Street shops =1, Mall $=0$.

Six surveyors performed surveys from 10 am to 7 pm in Lancry (26-27 June 2015). In La Défense, the same six surveyors conducted surveys from 10 am to $7 \mathrm{pm}$ (30 June 2015). Sampling was conducted using a convenience sampling method, and data were collected evenly across age group and gender. Before starting the surveys, the surveyors ensured there was "agreement to participate in the questionnaire" and that the participants were "were residents of Lancry or La Défense." Here, $60 \%$ of respondents participated in the survey and a total of 164 questionnaires were collected. Of the returned questionnaires, 94 were collected from residents of Lancry and 70 from residents of La Défense. In Lancry, the questionnaire was distributed among local residents passing through the streets where the shops are located, whereas in La Défense, the survey was distributed in residential areas, squares, or parks in the greater La Défense area rather than the shopping mall itself. Since the large shopping mall in La Défense is a commercial center with mass appeal, local residents, in addition to people coming from distant areas to shop, were potentially involved in the survey. For accuracy of communication, the questionnaire was a non-English version conducted in French. The collected questionnaires were coded using SPSS 21 statistical software (IBM, NEWYORK, USA).

\subsection{Research Design}

This study focuses on the influence of commercial activities on social bonding and place attachment among residents of a neighborhood. To accomplish this, we performed the following two-step model setting process. First, note that commercial activities will affect social bonding between residents as well as place attachment; this is because a larger amount of activity in a neighborhood allows for more opportunities to meet neighbors and experience the neighborhood. Second, note that commercial activities are influenced by satisfaction with the commercial and physical environments according to different commercial types (e.g., street shops or mall types), which are likely to affect commercial activities. 
This study uses two models. Model 1 analyzes each site individually to determine the effects of commercial activities on social bonding, as well as the direct and indirect effects of commercial activity on place attachment. A larger amount of commercial activities leads to higher activity in the neighborhood. The relationships between shop owners and neighbors are formed through the spaces in the neighborhood, such as shops and streets, and social bonding is an important factor that leads to attachment to the neighborhood. In addition, if people continue to use a space, they will develop feelings about that space, which can lead to place attachment. Model 2 analyzes the two sites combined to determine the different commercial types that affect commercial activities. The type of commercial environment, consisting of street shops or malls, can affect the commercial activities depending on accessibility. In the case of street shops, the shops are located near the houses and a pattern of frequent purchases of small quantities of goods will appear. However, accessibility in a mall-type commercial environment is lower than that for street shops, and instead exhibits a pattern of buying many goods at once.

\subsection{Data Analysis Using Path Analysis}

Based on the collected survey data, the following analysis process is conducted to confirm the purpose of this study. First, factor analysis is conducted based on questionnaire items to derive analysis factors. Second, correlation analysis is performed to analyze the correlation between factors and to remove factors with high relevance. Finally, analysis of the research model shown in Figure 3 is conducted through path analysis using the Amos program.

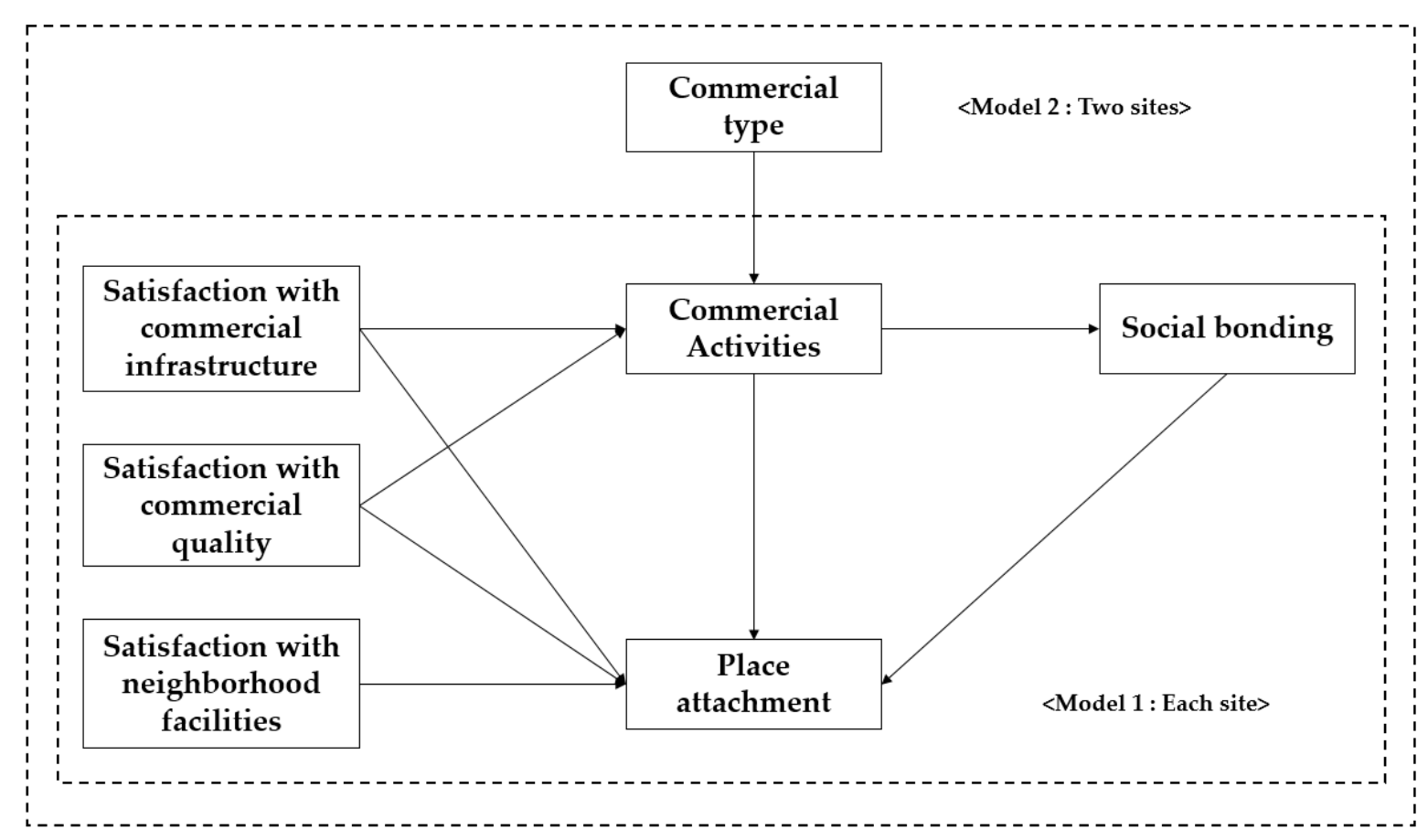

Figure 3. Research models.

Path analysis is a technique for explaining the causal relationships between variables in a non-experimental situation. The validity of the causal relationships between variables is examined using the collected data. The effects of any one variable on another variable are called direct effects, while the effects of one variable on one (or more) variable(s) by way of other variables are called indirect effect. The purpose of this study is to analyze direct and indirect effects of commercial activities on social bonding and place attachment, and effects of commercial types on commercial activities using path analysis based on collected data. 


\section{Results}

\subsection{Demographics and Factor Analysis}

The demographic characteristics of the subjects were as follows (see Table 2). Of 164 total subjects, 87 were males and 77 were females. In terms of age distribution, the highest proportion of the sample was people in their $30 \mathrm{~s}(24.4 \%)$, followed by those in their $20 \mathrm{~s}(23.8 \%)$, and those in their $40 \mathrm{~s}(14.6 \%)$. The average age of participants is 39.89 years old in Lancry and 34.22 years old in La Défense. The highest proportion of the sample claimed a residence period of $4-10$ years in a neighborhood $(31.7 \%)$, followed by $1-3$ years (21.3\%). In addition, $47 \%$ of the residents had lived for longer than 10 years in the neighborhood. Distribution according to site was $57.3 \%$ in Lancry and $42.7 \%$ in La Défense.

Table 2. Demographics.

\begin{tabular}{ccccc}
\hline \multirow{2}{*}{ Factors } & & Lancry & La Défense & Total \\
\cline { 3 - 5 } & & $\boldsymbol{N} \mathbf{( \% )}$ & $\boldsymbol{N} \mathbf{( \% )}$ & $\boldsymbol{N} \mathbf{( \% )}$ \\
\hline \multirow{3}{*}{ Sex } & Males & $51(54.3)$ & $36(51.4)$ & $87(53)$ \\
& Females & $43(45.7)$ & $34(48.6)$ & $77(47)$ \\
& Total & $94(100)$ & $70(100)$ & $164(100)$ \\
\hline \multirow{6}{*}{ Age } & $10 s$ & $7(7.4)$ & $15(21.4)$ & $22(13.4)$ \\
& $20 s$ & $23(24.5)$ & $16(22.9)$ & $39(23.8)$ \\
& $30 s$ & $20(21.3)$ & $20(28.6)$ & $40(24.4)$ \\
& $40 s$ & $17(18.1)$ & $7(10.0)$ & $24(14.6)$ \\
& $50 s$ & $16(17.0)$ & $4(5.7)$ & $20(12.2)$ \\
& $60 s$ and over & $11(11.7)$ & $8(11.4)$ & $19(11.6)$ \\
& Total & $94(100)$ & $70(100)$ & $164(100)$ \\
\hline \multirow{6}{*}{ Residence period } & $1-3$ years & $23(24.5)$ & $12(17.1)$ & $35(21.3)$ \\
& $4-10$ years & $26(27.7)$ & $26(37.1)$ & $52(31.7)$ \\
& $11-15$ years & $13(13.8)$ & $16(22.9)$ & $29(17.7)$ \\
& $16-20$ years & $16(17.0)$ & $10(14.3)$ & $26(15.9)$ \\
& 21 years & $16(17.0)$ & $6(8.6)$ & $22(13.4)$ \\
& Total & $94(100)$ & $70(100)$ & $164(100)$ \\
\hline
\end{tabular}

Factor analysis was performed twice. The first group included items related to commerce and neighborhood facilities, and the second group included items related to place attachment. The final factors are "satisfaction with commercial infrastructure" (SCI), "satisfaction with commercial quality" (SCQ), "satisfaction with 'neighborhood facilities" (SNF), "place attachment" (PA), "social bonding" (SB) (see Table 3), and "commercial activities" (CA). 
Table 3. Factor analysis.

\begin{tabular}{|c|c|c|c|}
\hline Factors & & Factor Loading & Cronbach's $\alpha$ \\
\hline \multirow{3}{*}{ Satisfaction with commercial infrastructure } & Necessary shops & 0.840 & \multirow{3}{*}{0.758} \\
\hline & Number of shops & 0.691 & \\
\hline & Distance to go to shops & 0.683 & \\
\hline \multirow{4}{*}{ Satisfaction with commercial quality } & Types of shops & 0.676 & \multirow{4}{*}{0.618} \\
\hline & Type and quality of products & 0.814 & \\
\hline & Price of products & 0.689 & \\
\hline & Service of shops & 0.654 & \\
\hline \multirow{3}{*}{ Satisfaction with neighborhood facilities } & Green space & 0.853 & \multirow{3}{*}{0.658} \\
\hline & Public and cultural facilities & 0.760 & \\
\hline & Pedestrian environment & 0.654 & \\
\hline \multirow{9}{*}{ Duration of residence } & Place identity 5 & 0.797 & \multirow{9}{*}{0.891} \\
\hline & Place dependence 2 & 0.765 & \\
\hline & Place identity 4 & 0.764 & \\
\hline & Place identity 1 & 0.758 & \\
\hline & Place dependence 3 & 0.745 & \\
\hline & Place dependence 4 & 0.713 & \\
\hline & Place identity 3 & 0.663 & \\
\hline & Place identity 2 & 0.660 & \\
\hline & Place dependence 5 & 0.594 & \\
\hline \multirow{4}{*}{ Social bonding } & Community 3 & 0.845 & \multirow{4}{*}{0.778} \\
\hline & Community 2 & 0.797 & \\
\hline & Community 1 & 0.757 & \\
\hline & Community 4 & 0.626 & \\
\hline
\end{tabular}

Table 4 shows that the averages for the factors are different according to the site. For SNF, the value for La Défense (3.55) was higher than the value for Lancry (3.14). However, for the other factors of PA (Lancry: 3.52; La Défense: 3.04), SB (Lancry: 2.98; La Défense: 2.75), SCI (Lancry: 3.65; La Défense: 3.42), SCQ (Lancry: 3.44; La Défense: 3.23), CA (Lancry: 2.80; La Défense: 2.31), and residence period (Lancry: 13.38; La Défense: 10.54), the values for Lancry were higher than the values for La Défense. Especially, CA in Lancry (2.80) was higher than in La Défense (2.31), which means that CA can vary depending on the commercial presence.

Table 4. Average value of factors ( $t$-test).

\begin{tabular}{|c|c|c|c|c|c|c|}
\hline Factors & Site & $N$ & Avg. & S.D. & S.E. & $t$ \\
\hline \multirow{2}{*}{ Satisfaction with commercial infrastructure } & Lancry & 94 & 3.65 & 0.63087 & 0.06507 & \multirow{2}{*}{$2.140 * *$} \\
\hline & La Défense & 70 & 3.42 & 0.76084 & 0.09094 & \\
\hline \multirow{2}{*}{ Satisfaction with commercial quality } & Lancry & 94 & 3.44 & 0.58294 & 0.06013 & \multirow{2}{*}{$2.248 * *$} \\
\hline & La Défense & 70 & 3.23 & 0.57972 & 0.06929 & \\
\hline \multirow{2}{*}{ Satisfaction with neighborhood facilities } & Lancry & 94 & 3.14 & 0.76911 & 0.07933 & \multirow{2}{*}{$-3.487^{* *}$} \\
\hline & La Défense & 70 & 3.55 & 0.69710 & 0.08332 & \\
\hline \multirow{2}{*}{ Social bonding } & Lancry & 94 & 2.98 & 0.75956 & 0.07834 & \multirow{2}{*}{$1.846 *$} \\
\hline & La Défense & 70 & 2.75 & 0.83839 & 0.10021 & \\
\hline \multirow{2}{*}{ Place attachment } & Lancry & 94 & 3.52 & 0.67531 & 0.06965 & \multirow{2}{*}{$4.495^{* * *}$} \\
\hline & La Défense & 70 & 3.04 & 0.69590 & 0.08318 & \\
\hline \multirow{2}{*}{ Commercial activities } & Lancry & 94 & 2.80 & 1.08039 & 0.11143 & \multirow{2}{*}{$2.956^{* * *}$} \\
\hline & La Défense & 70 & 2.31 & 1.02918 & 0.12301 & \\
\hline \multirow{2}{*}{ Duration of residence } & Lancry & 94 & 13.38 & 11.51913 & 1.18811 & \multirow{2}{*}{$1.931 *$} \\
\hline & La Défense & 70 & 10.54 & 7.25456 & 0.86709 & \\
\hline
\end{tabular}

\subsection{Path Analysis and Indirect Effects}

Path analysis was used to examine the effects of individual factors. Model 1 (Lancry model: $p=0.303, \mathrm{CMIN} / \mathrm{df}=4.851, \mathrm{RMR}=0.032, \mathrm{RMSEA}=0.048, \mathrm{GFI}=0.983, \mathrm{AGFI}=0.912, \mathrm{NFI}=0.964$, 
$\mathrm{IFI}=0.994, \mathrm{CFI}=0.993 ;$ La Défense model: $p=0.882, \mathrm{CMIN} / \mathrm{df}=0.295, \mathrm{RMR}=0.020, \mathrm{RMSEA}=0.000$, $\mathrm{GFI}=0.994, \mathrm{AGFI}=0.970, \mathrm{NFI}=0.974, \mathrm{IFI}=1.068, \mathrm{CFI}=1.000)$ is presented in Figure 4. CA (Lancry: $\beta=0.179, p<0.1$, La Défense: $\beta=0.340, p<0.01$ ) had a positive effect on SB, and SB (Lancry: $\beta=0.660$, $p<0.01$, La Défense: $\beta=0.226, p<0.1$ ) positively affected PA in both sites. However, the relationship between CA and PA is significant only in Lancry $(\beta=0.124, p<0.1)$.

SCI and SCQ did not have significant relationships with CA in either site, but they did affect PA in the Lancry model (SCI: $\beta=0.146, p<0.1$, SCQ: $\beta=0.161, p<0.05)$. On the contrary SNF $(\beta=0.253$, $p<0.05)$ affected PA only in the La Défense model.

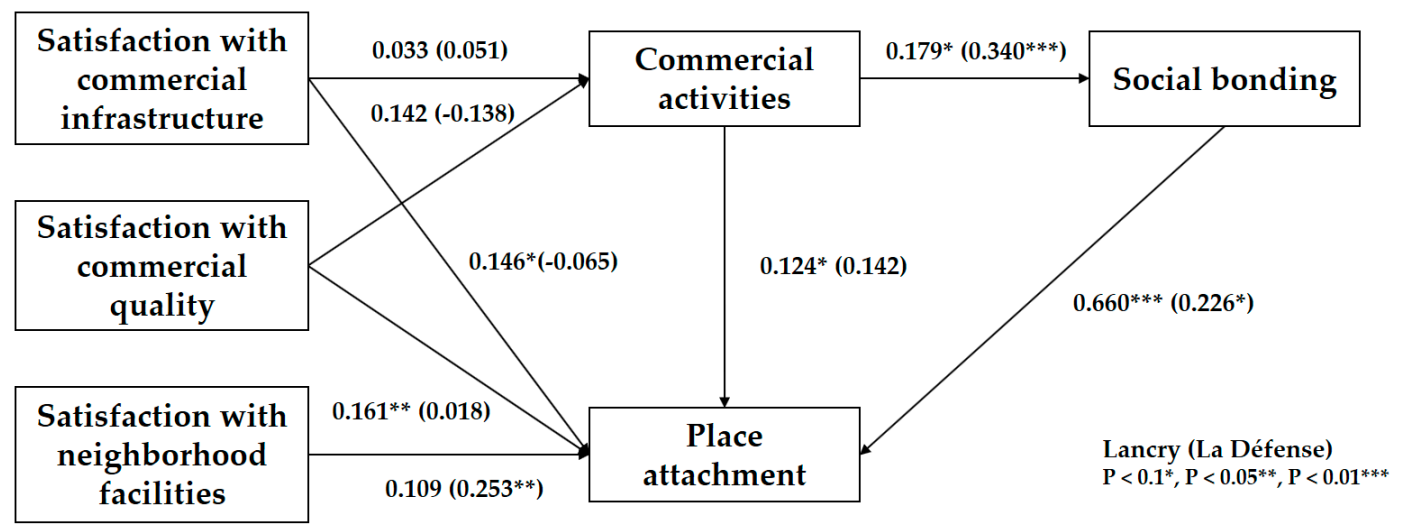

Figure 4. Path analysis of model 1.

Figure 5 presents a path analysis of model 2 for the two sites $(p=0.003, \mathrm{CMIN} / \mathrm{df}=3.275$, $\mathrm{RMR}=0.025, \mathrm{RMSEA}=0.118, \mathrm{GFI}=0.968, \mathrm{AGFI}=0.849, \mathrm{NFI}=0.883, \mathrm{CFI}=0.907)$. The results show what factors affect CA. In this model, only CT $(\beta=0.215, p<0.01)$ had positive effects on CA, while commercial satisfaction (e.g., SCI and SCQ) did not significantly affect CA. Further, CA affected SB $(\beta=0.272, p<0.01)$, while PA $(\beta=0.186, p<0.01)$ and SB $(\beta=0.305, p<0.01)$ significantly affected PA. Especially, the relationship between CA and PA here is stronger than that in model 1; the reason for this is the variability of CA was expanded by combining the data of the two sites.

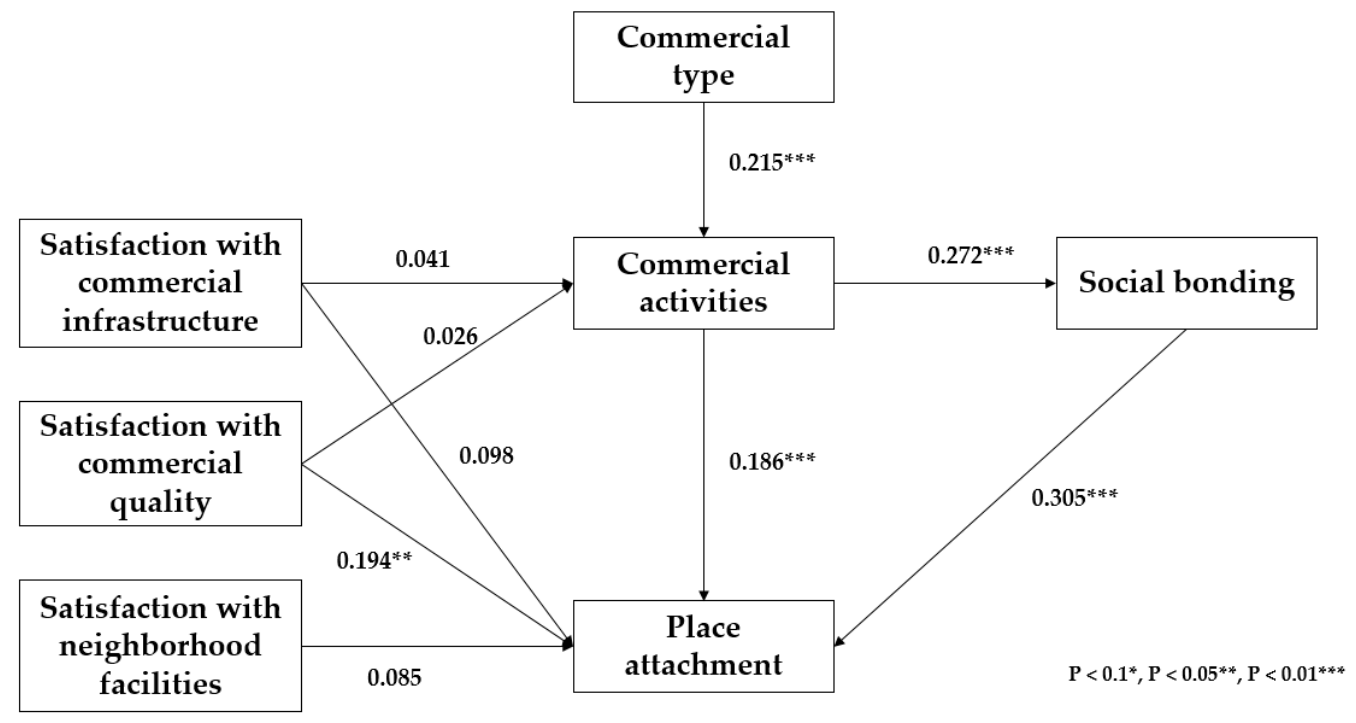

Figure 5. Path analysis of model 2.

Table 5 shows the indirect effects of CA through SB on PA. Analysis was conducted using two-tailed significance in Amos. First, in the Lancry case, the indirect effect of the path CA $\rightarrow$ SB $\rightarrow$ PA 
was $0.118(p<0.05)$, which was significant. In the La Défense, the indirect effect of $\mathrm{CA} \rightarrow \mathrm{SB} \rightarrow \mathrm{PA}$ was $0.076(p<0.05)$. Last, in the combined model, the indirect effect of CT $\rightarrow \mathrm{SB} \rightarrow \mathrm{PA}$ was $0.083(p<0.01)$, which was statistically significant.

Table 5. Analysis of indirect effects.

\begin{tabular}{cccccc}
\hline Model & Site & Path & Direct Effects & Indirect Effects & Total Effects \\
\hline \multirow{2}{*}{1} & Lancry & $\mathrm{CA} \rightarrow \mathrm{SB} \rightarrow \mathrm{PA}$ & 0.124 & $0.118^{* *}$ & 0.242 \\
& La Défense & $\mathrm{CA} \rightarrow \mathrm{SB} \rightarrow \mathrm{PA}$ & 0.142 & $0.076^{* *}$ & 0.218 \\
\hline 2 & Two sites & $\mathrm{CA} \rightarrow \mathrm{SB} \rightarrow \mathrm{PA}$ & 0.186 & $0.083^{* * *}$ & 0.269 \\
\hline \multicolumn{5}{c}{${ }^{*} p<0.1^{* *} p<0.05,{ }^{* * *} p<0.01}$. \\
\end{tabular}

\section{Discussion}

Previous studies have mainly focused on the satisfaction of residents with a specific place in terms of the relationship between the neighborhood environment and PA. In contrast, this study finds that $\mathrm{CT}$, which is the physical form of certain distinguishing characteristics in a neighborhood, affects the activities of people (such as CA) and that CA positively affects SB and PA. Place attachment (PA) refers to the emotions that a person has in connection to a specific place and his or her experience of activities therein. Accordingly, it was necessary to discuss not only people's primary satisfaction with the physical space, but also whether the characteristics of the physical environment led to certain types of human activity, thereby affecting level of PA. Therefore, this study analyzed the CT and CA, as well as SCI and SCQ as influencing factors of place attachment. The results are as follows.

First, PA was influenced by the satisfaction factors of the neighborhood environment, and PA differed in each case according to the neighborhood characteristics. Model 1 showed that Lancry and La Défense had different factors that influenced PA. Further, note that PA is a complicated emotion that is influenced by various factors. Therefore, high satisfaction with neighborhood environments can affect PA. In the case of Lancry, satisfaction with the commercial environment (SCI and SCQ) had a positive effect on PA because of the high density of shops and high accessibility. On the other hand, La Défense is a new city with appropriate walking areas (i.e., without cars), parks, green areas, and cultural facilities that have been well developed, thus, the neighborhood environment satisfaction (SNF) positively influenced PA.

Second, analysis of the neighborhood CT considering street shops and malls supports our hypothesis presented herein. It was confirmed that $\mathrm{CT}$ affects the $\mathrm{CA}$ of residents, however commercial satisfaction (SCI and SCQ) did not affect CA; this indicates that commercial satisfaction can improve the PA of people through emotional means, especially through the use of spaces. However, PA does not alter the pattern of shopping in daily life because people typically only buy products when they are needed. This finding confirmed that, in part, the higher value of CA of residents was found in the neighborhood with street shops than in the neighborhood with malls. From the standpoint of neighborhood design, this result shows that different types of commercial structures can produce different patterns of daily life in neighborhood residents. In a neighborhood with street shops, with a high shopping frequency, CT acts as a factor that increases opportunities among residents to meet with one another relative to these opportunities in neighborhoods with other commercial features. Therefore, it is expected that SB will increase in neighborhoods with street shops as well as the promotion of local affection among residents. This expectation is supported by the finding that CA has a positive effect on SB. Increased levels of activity lead to the accumulation of neighborhood experiences with other residents, which leads to the formation of bonds between locals and place attachment.

Finally, the most important factor in this study is the "activities" element. The results show that increased SB of residents is due to the CA of residents, which depends on the CT of neighborhoods. As a result of this study, we see that SB ultimately positively affects residents' PA to a neighborhood. The reason why SB is important in PA is not only the feelings of attachment that people have to a specific place, but also because the emotions felt by people identifying as members of a community 
through their relationships with neighbors is a factor in the formation of PA. The results show that SB has the greatest direct effect on PA $(\beta=0.278)$. Further, the mediating effects between CA and PA show the importance of SB in PA.

\section{Conclusions}

The results of this study confirm that the CA among people in neighborhoods is an influencing factor with respect to the SB and PA of local residents, and that CA can be varied by changing CT. Based on the results of the study, two measures could be proposed as measures to increase place attachment in locals for sustainable neighborhood environments. The accumulation of experiences in places and bonding among local people are the methods whereby place attachment is formed. These are items that can be promoted based on the activities of residents in a neighborhood. In particular, this study analyzes the daily activities of residents in terms of their commercial activities, which provides implications for community and neighborhood design with regard to commercial features. The commercial environments of neighborhoods and the commercial activities occurring therein are basic activities in the daily lives of people. Until now, the focus on commercial features in urban design and neighborhood environments has been solely on physical quality and satisfaction. However, the results of the study demonstrate that the commercial environment is not simply a place to facilitate purchase transactions among residents. The commercial environment is an important factor that increases bonding among the people in neighborhoods and strengthens the attachment of locals to their place.

In order to promote the commercial activities of residents in neighborhoods, it is necessary to design neighborhoods that consist of small-scale stores rather than large-scale mall-type stores. However, current commercial spaces are becoming larger than ever. As a result of the decline of small-scale stores-a potential place for interaction and communication among locals-opportunities for exchange activities among residents have decreased. In addition, when small-scale merchants are replaced by large shopping malls, independent stores with diverse personalities tend to disappear. Over time, the unique characteristics of each trade will be replaced by the uniformity of commercial franchises. From the point of view of residents, favorite shops are disappearing, and there are fewer places where they want to go. This can have a negative impact on the formation of place attachment, as the appealing features of neighborhood local commerce are lost.

In order to create neighborhoods that people want to live in, place attachment via social bonding should be strengthened, and urban design that increases the activities of residents in neighborhoods should be reflected. From this point of view, this study suggests that small commercial spaces, such as street shops, are more effective than large malls in enhancing local attachment.

Author Contributions: B.K. conceived the idea and designed this research. J.P. developed the idea for academic research and reviewed the manuscript as a corresponding author. All authors carried out data collection and analysis, and drafted the manuscript.

Acknowledgments: This research was supported by Basic Science Research Program through the National Research Foundation of Korea (NRF) funded by the Ministry of Education (NRF-2017R1D1A1A09000940) and modified based on "Effects of Commercial Environment on Community and Place Attachment in Neighborhoods", 2016 Spring Congress Korea Planning Association (proceeding), Seoul, Korea.

Conflicts of Interest: The authors declare no conflict of interest.

\section{Abbreviations}

$\begin{array}{ll}\text { PA } & \text { Place attachment } \\ \text { SB } & \text { Social bonding } \\ \text { CA } & \text { Commercial activities } \\ \text { CT } & \text { Commercial type } \\ \text { SCI } & \text { Satisfaction with commercial infrastructure } \\ \text { SCQ } & \text { Satisfaction with commercial quality } \\ \text { SNF } & \text { Satisfaction with neighborhood facilities }\end{array}$




\section{References}

1. Low, S.M.; Altman, I. Place attachment. In Place Attachment; Springer: Boston, MA, USA, 1992; pp. 1-12.

2. Hidalgo, M.C.; Hernandez, B. Place attachment: Conceptual and empirical questions. J. Environ. Psychol. 2001, 21, 273-281. [CrossRef]

3. Bailey, N.; Kearns, A.; Livingston, M. Place attachment in deprived neighbourhoods: The impacts of population turnover and social mix. Hous. Stud. 2012, 27, 208-231. [CrossRef]

4. Liu, Y.Q.; Wu, F.L.; Liu, Y.; Li, Z.G. Changing neighbourhood cohesion under the impact of urban redevelopment: A case study of Guangzhou, China. Urban Geogr. 2017, 38, 266-290. [CrossRef]

5. Kim, D. A Study on the Place Attachment of Residential Environment-Focused on Multilevel Analysis Using SEM and HLM. Ph.D. Thesis, Seoul National University, Seoul, Korea, 2008.

6. Lewicka, M. Place attachment: How far have we come in the last 40 years? J. Environ. Psychol. 2011, 31, 207-230. [CrossRef]

7. Kaltenborn, B.P.; Bjerke, T. Associations between landscape preferences and place attachment: A study in Røros, Southern Norway. Landsc. Res. 2002, 27, 381-396. [CrossRef]

8. Brown, G.; Brown, B.B.; Perkins, D.D. New housing as neighborhood revitalization-place attachment and confidence among residents. Environ. Behav. 2004, 36, 749-775. [CrossRef]

9. Choi, E.; Yim, H. The perception and the determinants of place attachment. J. Korea Plan. Assoc. 2005, 40, 53-64.

10. Zhu, Y.S.; Breitung, W.; Li, S.M. The changing meaning of neighbourhood attachment in Chinese commodity housing estates: Evidence from Guangzhou. Urban Stud. 2012, 49, 2439-2457. [CrossRef]

11. Park, J.; Kim, B. Influence of residents' attachment to the community on participation in community-building activities-focusing on hannam 1 dong. J. Urban Des. Insit. Korea 2014, 15, 215-226.

12. Hernandez, B.; Hidalgo, M.C.; Salazar-Laplace, M.E.; Hess, S. Place attachment and place identity in natives and non-natives. J. Environ. Psychol. 2007, 27, 310-319. [CrossRef]

13. Nielsen-Pincus, M.; Hall, T.; Force, J.E.; Wulfhorst, J.D. Sociodemographic effects on place bonding. J. Environ. Psychol. 2010, 30, 443-454. [CrossRef]

14. Handy, S.L.; Boarnet, M.G.; Ewing, R.; Killingsworth, R.E. How the built environment affects physical activity-views from urban planning. Am. J. Prev. Med. 2002, 23, 64-73. [CrossRef]

15. Saelens, B.E.; Sallis, J.F.; Black, J.B.; Chen, D. Neighborhood-based differences in physical activity: An environment scale evaluation. Am. J. Public Health 2003, 93, 1552-1558. [CrossRef] [PubMed]

16. Rosenberg, D.; Ding, D.; Sallis, J.F.; Kerr, J.; Norman, G.J.; Durant, N.; Harris, S.K.; Saelens, B.E. Neighborhood environment walkability scale for youth (news-y): Reliability and relationship with physical activity. Prev. Med. 2009, 49, 213-218. [CrossRef] [PubMed]

17. Van Dyck, D.; Cardon, G.; Deforche, B.; Sallis, J.F.; Owen, N.; De Bourdeaudhuij, I. Neighborhood SES and walkability are related to physical activity behavior in belgian adults. Prev. Med. 2010, 50 (Suppl. 1), S74-S79. [CrossRef] [PubMed]

18. Ding, D.; Sallis, J.F.; Kerr, J.; Lee, S.; Rosenberg, D.E. Neighborhood environment and physical activity among youth a review. Am. J. Prev. Med. 2011, 41, 442-455. [CrossRef] [PubMed]

19. Cerin, E.; Macfarlane, D.J.; Ko, H.H.; Chan, K.C.A. Measuring perceived neighbourhood walkability in Hong Kong. Cities 2007, 24, 209-217. [CrossRef]

20. Shigematsu, R.; Sallis, J.F.; Conway, T.L.; Saelens, B.E.; Frank, L.D.; Cain, K.L.; Chapman, J.E.; King, A.C. Age differences in the relation of perceived neighborhood environment to walking. Med. Sci. Sports Exerc. 2009, 41, 314-321. [CrossRef] [PubMed]

21. Williams, D.R.; Roggenbuck, J.W. Measuring Place Attachment: Some Preliminary Results. Available online: https:/ / www.fs.fed.us/rm/value/docs/nrpa89.pdf (accessed on 18 May 2018).

22. Proshansky, H.M. The city and self-identity. Environ. Behav. 1978, 10, 147-169. [CrossRef]

23. Yoon, Y.; Kwock, Y. Residents' place attachment in evaluating tourism destination. J. Hotel Resort 2005, 4, 511-525.

24. Lee, E. The intrinsic attributes of place attachment: In case of a poem Dashi Elle ege (to Elle again). J. Cult. Hist. Geogr. 2006, 18, 1-10. 
25. Li, X.; Kleinhans, R.; van Ham, M. Ambivalence in Place Attachment: The Lived Experiences of Residents in Declining Neighbourhoods Facing Demolition in Shenyang, China; IZA Institute of Labor Economics: Bonn, Germany, 2017.

26. Lewicka, M. What makes neighborhood different from home and city? Effects of place scale on place attachment. J. Environ. Psychol. 2010, 30, 35-51. [CrossRef]

27. Bonaiuto, M.; Aiello, A.; Perugini, M.; Bonnes, M.; Ercolani, A.P. Multidimensional perception of residential environment quality and neighbourhood attachment in the urban environment. J. Environ. Psychol. 1999, 19, 331-352. [CrossRef]

28. Pretty, G.H.; Chipuer, H.M.; Bramston, P. Sense of place amongst adolescents and adults in two rural Australian towns: The discriminating features of place attachment, sense of community and place dependence in relation to place identity. J. Environ. Psychol. 2003, 23, 273-287. [CrossRef]

29. Norman, G.J.; Nutter, S.K.; Ryan, S.; Sallis, J.F.; Calfas, K.J.; Patrick, K. Community design and access to recreational facilities as correlates of adolescent physical activity and body-mass index. J. Phys. Act. Health 2006, 3, S118-S128. [CrossRef] [PubMed]

30. Pate, R.R.; Colabianchi, N.; Porter, D.; Almeida, M.J.; Lobelo, F.; Dowda, M. Physical activity and neighborhood resources in high school girls. Am. J. Prev. Med. 2008, 34, 413-419. [CrossRef] [PubMed]

31. Nagel, C.L.; Carlson, N.E.; Bosworth, M.; Michael, Y.L. The relation between neighborhood built environment and walking activity among older adults. Am. J. Epidemiol. 2008, 168, 461-468. [CrossRef] [PubMed]

32. Wood, L.; Frank, L.D.; Giles-Corti, B. Sense of community and its relationship with walking and neighborhood design. Soc. Sci. Med. 2010, 70, 1381-1390. [CrossRef] [PubMed]

33. Leyden, K.M. Social capital and the built environment: The importance of walkable neighborhoods. Am. J. Public Health 2003, 93, 1546-1551. [CrossRef] [PubMed]

34. Kim, J.; Kaplan, R. Physical and psychological factors in sense of community-new urbanist kentlands and nearby orchard village. Environ. Behav. 2004, 36, 313-340. [CrossRef]

35. KelQuartier. Available online: http://www.kelquartier.com/ile_de_france_paris_paris_10_quartier_ chateau_d_eau_lancry_75010-q100518/revenu_moyen.html (accessed on 18 May 2018). (In France)

36. KelQuartier. Available online: http://www.kelquartier.com/ile_de_france_hauts_de_seine_puteaux_ quartier_la_defense_92800-q100352/revenu_moyen.html (accessed on 18 May 2018). (In France)

37. Kang, S. The Impact of Community Attachment on the Attitudes toward Tourism Development; Hanyang: Seoul, Korea, 2001.

(c) 2018 by the authors. Licensee MDPI, Basel, Switzerland. This article is an open access article distributed under the terms and conditions of the Creative Commons Attribution (CC BY) license (http:/ / creativecommons.org/licenses/by/4.0/). 